\title{
Localizing of Community Resilience Indicators for Assessing the Urban Community Resilience in Putrajaya, Malaysia
}

\author{
Norhidayah Mohamad, Hamzah Jusoh, Zarina Kassim
}

\begin{abstract}
The resilient concept has been widely used by major world cities as one of the strategies in tackling shocks and stresses and become more resilient to the physical, social and economic challenges. This concept helps in building a resilient community with a high-quality, proactive and dynamics which capable of addressing the challenges of urbanization. Urbanization leads to widening income inequality, high dependency on government and lack of social cohesion significantly affect the social lives of the urban community. This paper aims to localize the resilience community indicators for measuring the resilience level of the urban community in Putrajaya. The aspect studied is localizing the resilience community indicators of the urban community. This research used a qualitative approach by a semi-structured interview. The population of the study consists of three experts in resilient concept as well as community development and three main informants who lived in Putrajaya. The researcher believes that by building a resilient community, indirectly the urban community will be more prepared for the challenges of modernity in the future and move in tandem with the big cities of the world. Therefore, the emphasis of the resilience concept able to improves the quality of the community and enhances community development.
\end{abstract}

Keywords: Localizing, Community Resilience Indicators, Resilient Community, Urban Community, Community Development

\section{INTRODUCTION}

Creating a resilient community is a requisite by identifying strengths, weaknesses, opportunities and challenges for future development of the community. Hence, the concept of resilient community should be adopted, nurtured and enhanced by every individual, community and society in order that their role is more progressive, dynamic and competitive. A change in world trends which is The Third Globalization raises the question as to how the communities are able to survive and thrive in the new era of trade, taxation and political uncertainty. Apart from that, The Fourth Industrial Revolution where various new technologies combine the physical, digital and biological worlds that affect all disciplines including civil society and how civil society will respond and adapt to the coming transition. In accordance with the opinion of Prof. Emeritus Dr. Barjoyai Bardai, the era of industrial revolution will create widespread income gap across the continent, classes,

Revised Manuscript Received on April 19, 2019.

Norhidayah Mohamad, Faculty of Social Science and Humanities, Universiti Kebangsaan Malaysia, Bangi, Selangor, Malaysia.

Prof. Dr. Hamzah Jusoh, Professor, Faculty of Social Science and Humanities, Universiti Kebangsaan Malaysia, Bangi, Selangor, Malaysia.

Zarina Kassim, Researcher, Faculty of Economics \& Administration, University of Malaya, Malaysia. gender and employment. It includes the aspect of materialism and also the eradicated of human values and justice (1). Furthermore, (2) also believes that the era of the industrial revolution is capable of changing the humanitarian value due to the tendency of human being to act as a machine characterized by speed, efficiency, intelligence and relentless even human beings reject the values of humanity such as justice, compassion, universality, warmth and prosperity.

Urbanization is also one of the trends that change the world consequentially affecting the lives of the people and estimate that $80 \%$ of the world's population lives in urban areas by 2030. Nowadays, more than half of the world's population is now migrating and living in urban areas to enjoy better lives and widespread opportunities. This illustrates the population increasing from year to year and this has further increased the density of the populations in the country. The growth of urban populations and density puts pressure on the city as well as local communities. (ㅈ) has stated urban community's face the challenges of various shocks and stresses whether a natural disaster or man-made disasters such as rapid urbanization, climate change, terrorism and the increased risk from a natural hazard. The increase in the country's urbanization rate, the era of the fourth industrial revolution is seen to have an impact on the lives of urban communities.

The development of Putrajaya which includes network infrastructure of international standards, the country's main administrative center and knowledge society has made Putrajaya as a well-planned city. As a well-planned and fastpaced city, Putrajaya also viewed inseparable from the challenges and stresses that affect the development of the urban community. Rising issues such as neglect of social responsibility, no initiatives in social cohesion and decreasing in practicing good values indicate the resilience of the community at an unfavorable level. This is reinforced by the research conducted by (4), the findings show that the level of social participation of urban residents in the neighborhood of Putrajaya is at a low level.

A low level of social participation among neighborhoods when organizing activities indicates weakness in urban communities. This shows a situation in contrast to the picture of the community in Putrajaya which comprising elite and educated classes of society. Community in Putrajaya are mostly employed as civil servants are 
supposed to emphasize and aware of the importance of social participation. Community development based on the concept of community resilience is a positive shift to society as well as to the country in addressing those challenges and changes.

These issues should be discussed comprehensively to implement and maintain the characteristics of a resilient community such an inclusive community, livability and spirit of unity. To meet the new era of change while moving along Malaysia towards a developed nation by the year 2030 , the concept of resilience community should be applied to community development as a balance in society needs to be achieved to create a society of high resilience to meet current needs and drive the transformation of the nation.

\section{LITERATURE REVIEW}

\section{A. Resilience Indicators}

Resilience is a term emerging from ecology in the 1970s, to reflect the system's capacity in maintaining and restoring functions in the event of a disruption. This concept is seen as fit in the development of resilient community because the community is a human being who undergoes a complex system and needs adapt to any changing circumstances. In evaluating community resilience, references to resilience systems built by ( $\underline{3})$ have shown detailed analysis. The analysis is based on the following urban resilience; basic needs, livelihood support, health management, law enforcement, social harmony, information management and knowledge, capacity and coordination, critical infrastructure management, environmental management, strategy and city planning, economic sustainability and accessibility. The quality of the resilience system is measured on the themes identified by the city's stakeholders. It is one of the city's important functions to increase resilience.

In addition, (ㅁ) stated that the history, culture, experience, planning and different city context distinguish the community. Clearly, the development of the city indirectly affects community development. This is because the community is part of the city itself. Accordingly, the valuation analysis of the resilience system by (ㄱ) helped in localizing and building community resilience indicators. This method is also supported by the study by (ㅁ) in building a Community Resilience Index (CRI). They state that there are some opportunities to improve existing indicators in continuing the thinking, measurement and analysis of community resilience. To get an accurate picture of community resilience it requires a mixed strategy. Resilience valuation relies on existing indicators to map and monitor trends in community intelligence and potential weaknesses. Existing indicators, if carefully selected, can be used to assess community resilience after unplanned events that challenge the adaptive capacity of the community.

\section{B. Community Resilience Indicators}

To what extent community resilience indicators that have been developed by scholars in the past study can help to localize the community resilience indicator for assessing the level of urban community resilience. Therefore, assessments of the various existing indicators include resilience indicators and resilience community indicators have shown the strengths and weaknesses that need to be adjusted based on the study will be conducted.

The study conducted by Longstaff and its colleagues has shown the use of community resilience indicators according to the research they conducted. According to (ㅁ) among the criteria for community resilience is the ability of communities to absorb disturbances while maintaining the main functions. Communities that have the resources robustness and adaptive capacity with the highest level will be the most resilient. In the study Building Resilient Community: A Preliminary Framework for assessment by ()), they introduced the Resilience Analysis Breakdown by stating that the functions and resources under each subsystem which included evaluation criteria and indicators for each resilience feature which are performance, redundancy, diversity, institutional memory, innovative learning and connectedness.

\section{Urban Community Resilience Indicators}

According to Carpenter et al. (2001) in (7) the challenge in building measurements for resilience lies in the diversity of resilience and involves questions about what resilience and what. Communities can be regarded as resilient to the changing trend when the community is more independent, dynamic and willing to move in tandem with developments and daring to take risks. Assessing urban community resilience requires specific indicators. Hence, through the process of localizing resilience indicators, community resilience indicators, resilience community indicators towards disaster and qualitative findings of this research in line with desired research have formed urban community resilience indicators. After reviewing past studies, the Community Capacity Conceptual Model by (모) has been adapted and became the main dimension of the study. Elements of community capacity model are also used as a specific theme in explaining the resilience of this community indicator. Focused urban community resilience indicators are seen to guide more specific and comprehensive towards desired research.

Dimension and Main Theme

Localizing urban community resilience indicators has been set up through several stages. Community capacity is [1] one dimension of this study. Key themes identified based on the resilience of the community studied. The urban community resilience indicators have touched on [3] three themes that are represented in the community capacity model, namely economic capital, social capital and environmental capital.

\section{Indicators}

The term "indicators" refers to the general condition or factor associated with the resilience of the community. Some community resilience indicators were developed to complement the conceptual framework built to assess the community's capacity and the latest community resilience level. The indicators are based on scientific research literature and are represented in significant urban community resilience and application. The indicators 
presented in this study are the preliminary framework for research use and are used to identify and develop a relevant assessment for urban community resilience level in fieldwork. Table 1 shows a summary of urban resilience indicators before localizing has been made.

Table 1. A Summary of Urban Resilience Indicators before Localizing

\begin{tabular}{|c|c|c|}
\hline \multicolumn{3}{|c|}{ Dimension: Community Capacity Wilson (2012) } \\
\hline Themes & Previous Studies & $\begin{array}{l}\text { Selected } \\
\text { Indicators }\end{array}$ \\
\hline \multirow[t]{3}{*}{$\begin{array}{l}\text { Economic } \\
\text { Capital }\end{array}$} & $\begin{array}{l}\text { Median household } \\
\text { income }(\underline{6})\end{array}$ & $\begin{array}{l}\text { Employment } \\
\text { and income }\end{array}$ \\
\hline & $\begin{array}{l}\text { Dynamic local } \\
\text { business } \\
\text { development and } \\
\text { innovation }(\underline{3})\end{array}$ & $\begin{array}{l}\text { Generating side } \\
\text { income }\end{array}$ \\
\hline & $\begin{array}{l}\text { Attractive } \\
\text { business } \\
\text { environment }(\underline{3})\end{array}$ & $\begin{array}{l}\text { Business } \\
\text { opportunity }\end{array}$ \\
\hline \multirow[t]{3}{*}{ Social capital } & $\begin{array}{l}\text { Local community } \\
\text { support }(\underline{3})\end{array}$ & $\begin{array}{l}\text { Community } \\
\text { social support }\end{array}$ \\
\hline & $\begin{array}{l}\text { Actively engaged } \\
\text { citizens }(\underline{3})\end{array}$ & $\begin{array}{l}\text { Active } \\
\text { involvement }\end{array}$ \\
\hline & $\begin{array}{l}\text { Variety of non- } \\
\text { profit } \\
\text { organizations }(\underline{6})\end{array}$ & $\begin{array}{l}\text { Urban } \\
\text { community } \\
\text { resident } \\
\text { associations }\end{array}$ \\
\hline \multirow[t]{3}{*}{$\begin{array}{l}\text { Environmental } \\
\text { capital }\end{array}$} & $\begin{array}{l}\text { Accountability, } \\
\text { service delivery } \\
(\underline{6})\end{array}$ & $\begin{array}{l}\text { Governance of } \\
\text { community } \\
\text { associations }\end{array}$ \\
\hline & $\begin{array}{l}\text { Devolved, layered } \\
\text { government }(\underline{6})\end{array}$ & $\begin{array}{l}\text { Networking } \\
\text { with } \\
\text { government }\end{array}$ \\
\hline & $\begin{array}{l}\text { Variety of } \\
\text { habitats, flora and } \\
\text { fauna (ㅁ) }\end{array}$ & $\begin{array}{l}\text { Protect the } \\
\text { environment }\end{array}$ \\
\hline
\end{tabular}

\section{METHODOLOGY}

\section{A. Research Design}

The design of the study is a plan, structure and research strategy that is considered to find the answers to the research questions. It includes the guidelines to be undertaken by the researcher from writing hypotheses and their operational implications to the latest data analysis (Kerlinger,1986) in (9).

This study is a descriptive methodology using survey research methodology covering interview technique. A survey is defined as a method of research involving the collection of data on the population to understand the current situation in relation to population and one or more variables $(\underline{10})$. By using survey research methods, the researcher is able to study the social phenomena that occur in the community such as community resilience towards current issues and changes in national trend.

This research has adapted indicators to assess urban community resilience indicators specifically for the urban community in Putrajaya. The development of the indicator process was developed based on secondary data research from previous studies and the localizing process by conducting consultant expert interviews and key informants to confirm the suitability of the indicators and observation using inductive research. The indicators are made up of one [1] dimension and three [3] themes.

\section{B. Sampling Technique}

Qualitative data for this study were collected in order to localize the urban community resilience indicators. The number of samples for qualitative data is small and nonrandom. The sample was selected by using non-probability sampling which is purposive sampling. For this type of sampling, sample selections have been identified based on predetermined criteria. In order to achieve the objective of the study, the researcher has chosen purposive sampling. The researcher uses purposive sampling because it refers to a sampling procedure that sets a set of subjects that have certain criteria as a respondent based on the knowledge and specific purpose of the study.

For the study of urban community resilience indicators, qualitative data involves the selection of experts and key informants. The sampling is intended to be used by placing some of the criteria that meet the objectives of the study which are university expert, CUEPACS, Perbadanan Putrajaya ( $\mathrm{PPj}$ ), non-governmental organization (NGO), religious institution and community leader. The researcher selected a sample of the study based on one of the set criteria. For example, one of the experts in this study is a lecturer from the International Islamic University of Malaysia with knowledge and expertise in urban management and community planning. One of the main informant for this study is the chairman of the NonGovernmental Organizations (NGOs) who is always engaged in activities involving the local community. The number of samples for this study was added until the analyzed data reached a saturated level and no further information was obtained despite incremental samples.

\section{Research Instrument}

Answering research questions is a requirement for research conducted. Therefore, every researcher needs to have a valid instrument and has the ability to collect data to answer each question $(\underline{10})$. The instrument that has been used by the researcher in conducting field research is by using a set of interview questions. The interview process is done verbally and the answers obtained will be recorded by the researcher. This method allows researchers to obtain more information and obtain explanations from experts and key informants. Researcher chooses to use pre-encode methods to facilitate the process of collecting information during an interview.

This method enables the researcher to review certain items without copying the response from interviewing participants.

\section{RESULTS AND FINDINGS}

\section{A. Qualitative Findings}

The findings were compiled from interviewing experts and key informants on urban community resilience concept, current issues among urban communities and localized the 
International Conference on Recents Advancements in Engineering and Technology (ICRAET-18) |15th and 16th March 2019|Siddhartha Institute of Technology \& Sciences, Telangana, India.

local indicators for assessing of urban community resilience level in Putrajaya. All the themes have been developed through the transcript, analysis and coding of qualitative data using ATLAS. ti software. The analysis of qualitative data is described in detail and clear graphics displays together with a summary table of the themes were included in the end.

During the interview process, the researcher has provided a protocol of interviews with the indicator for measuring the resilience of the urban community through localize indicators that are relevant to this study. The researchers have changed the names of the referring experts and key informants with certain codes to protect the confidentiality of their identity. The codes used by researchers are IU01, PR02, IU03, PR04, PR05 and IU06. IU is the code for the key informants, while PR is the code for the experts. The number behind the code refers to the arrangement of interviews conducted by the researcher.

\section{B. Background of Experts and Key Informants}

There are six people who have been chosen as experts and key informants. Three [3] experts consist of those who have expertise in community development, municipalities, as well as administration. Meanwhile, key informants were those who inhabited the city of Putrajaya and more aware and concerned deepen residence, life and lifestyle as well as issues in the community, especially in Putrajaya city. The results of the interview data have further convinced researcher that experts and key informants were qualified participants to provide cooperation and information on this study. Table 2 shows the background of the interviewing participants.

Table 2. The Background of Experts and Key Informants

\begin{tabular}{|c|c|c|c|}
\hline Code & Position & $\begin{array}{c}\text { Experienc } \\
\mathrm{e}\end{array}$ & Selection Criteria \\
\hline $\begin{array}{l}\text { PR0 } \\
2\end{array}$ & $\begin{array}{l}\text { CUEPACS } \\
\text { Highest } \\
\text { Officer }\end{array}$ & 10 years & CUEPACS \\
\hline $\begin{array}{l}\text { PR0 } \\
4\end{array}$ & Lecturer & 8 years & $\begin{array}{l}\text { University Expert } \\
\text { in Urban and } \\
\text { Regional Planning }\end{array}$ \\
\hline $\begin{array}{l}\text { PR0 } \\
5\end{array}$ & $\begin{array}{l}\text { Principal } \\
\text { Assistant } \\
\text { Director of } \\
\text { Perbadanan } \\
\text { Putrajaya }\end{array}$ & 12 years & $\begin{array}{l}\text { Perbadanan } \\
\text { Putrajaya (PPj) }\end{array}$ \\
\hline IU01 & $\begin{array}{l}\text { Chairman of } \\
\text { the Kelab } \\
\text { Komuniti } \\
\text { Prihatin } \\
\text { Putrajaya }\end{array}$ & $\begin{array}{l}2 \text { years } 8 \\
\text { months }\end{array}$ & $\begin{array}{l}\text { Non-governmenta } \\
1 \text { Organization } \\
(\mathrm{NGO})\end{array}$ \\
\hline IU03 & $\begin{array}{l}\text { Chief Imam } \\
\text { of Masjid } \\
\text { Mahmoodiah } \\
\text {, Putrajaya }\end{array}$ & 5 months & $\begin{array}{l}\text { Religious } \\
\text { Institutions }\end{array}$ \\
\hline IU06 & $\begin{array}{l}\text { Chairman of } \\
\text { Residents } \\
\text { Association }\end{array}$ & 9 years & $\begin{array}{l}\text { Community } \\
\text { Leader }\end{array}$ \\
\hline
\end{tabular}

\section{Localizing of Urban Community Resilience Indicators}

The current research has adapted indicators from previous studies by (ㅁ), (므) and (므) before the localizing process has been made (Table 3). However, the result findings are shown these adapted indicators are not adequate enough to the urban community in Putrajaya. In assessing urban community resilience level, the researcher has been taken the localizing process in order to build a comprehensive guide for this research. In this section, the localized indicators are explained through several sub-themes consists of economic capital, social capital and environmental capital.

\section{1) Economic Capital}

Economic capital is one of the important indicators in assessing the resilience of the urban community, especially from the economic point of view of individuals, families and community. Each sub sub-themes within the sub-theme help in evaluating how far the urban community's current economic position is. From the analysis and localizing, the researcher has found out several additional indicators for the economic capital. As mention by the experts and key informants, the level of education and income of the individual affects the resilience of urban community especially on these days. Based on the statement by them, they believe the dependency of individuals and families on income. The individual employment status is also one of the indicators agreed by the key informant. Individual status affects the resilience of the urban community through the way they thinking and making a decision.

"Employment status.. Of course, it is very influential. Why do i say so.. We can see various grades in government sector. Subordinates grade would think in this way while the top grade would think in a different way". (IU01/1:23).

Besides, the rising cost of living is one of the factors that affect the resilience of the urban community where people feel the change in prices of goods, rising fuel prices and so on. Both experts and key informants agreed with this factor as stated

"Give affect because the cost price of the goods increases". He added, "It should be enough, but with the current economic situation it is not enough where one person has to do more jobs, especially for the B40s. They make two jobs for their lives to be more comfortable and maintain". (PR02/2:15).

The devaluation of the ringgit also affects the economy of the people especially the urban community as the current economy is decaying and not as vibrant as before. As mentioned by experts

"It affects because of the cost of the price of goods rising, the value of the currency drops and the political changes". (PR02/2:12).

In addition to the ringgit's devaluation, political change also played a large role in the transformation towards new government and community acceptance. Other than that, something that affects the urban community's resilience from an economic point of view can also be evaluated

Blue Eyes Intelligence Engineering

\& Sciences Publication 
through side income. The urban community also has initiatives to improve their family's income. One of the experts also agrees with generating side income

"Yes definitely for now. Even lecture also do side job to maintain the high cost of living". (PR04/4:10).

The increasing number of people who do online business within the community has proven the business is among the contributors to the economic aspects of the urban community. The experts also believed the best of the business opportunity. A vibrant economy forms a rapid development. People will be quickly build up like a business community where they realize they need to build up and stronger after facing any challenges which are important for the development process.

\section{2) Social Capital}

Social capital is a major argument especially in identifying suitable indicators to measure the resilience of the urban community. The community that is actively involved is one of the factors that develop the resilience in the community. Based on one of the key informant

"Each and every event carried out, we get very good feedback after two years. It is important because the community looks for the successfulness of the event". (IU01/1:30).

The spirit of belonging within the urban community shown as when there is cooperation for night watch between communities in order to fight crime within their resident area. In addition, local community support in activities also plays a role in the social aspects of the community. The extent of community supports in the big events either religious activities, sports activities and resident associations activities. Subsequently, the association of urban community residents played a part in the development of the community. In order to measure the resilience of the urban community, the association of urban community residents created the social capital of the community.

The unity of the people plays a role in the interconnected community. The experts also emphasize the importance of establishing community-based urban community associations and the leader should be actively involved with the local government. As stated by expert

"Definitely it is important for connectedness between resident's organizations and their local authority which is Perbadanan Putrajaya”. (PR04/4:12).

With the establishment of an association of residents, community ties through association also implemented. These developments affect the survival of the community when viewed from social apathy through the social network between the administrators and the community of their fellow community. Community social support also one of the important indicators in social capital as the support of the community becomes a positive attribute for the urban community.

\section{3) Environmental Capital}

Discussing the environmental capital, the resilience of the urban community involves the environment where the community resides and community governance where communities have a transparent relationship with local governments and their community administrations.
According to experts, the community of the city also has the initiative of utilizing natural sources as the community able to plant while living in quarters shows a good initiative. Furthermore, besides initiatives utilizing natural resources through planting trees, initiatives to protect the environment is also important especially in urban community life. The community in line with the government supporting the go green event through prohibits the use of polystyrene, use bio-degradable plastic and community activities such as communal work.

Networking with the government is one of the key indicators in which the role of direct urban community engagement with local leaders on building resilient community as well as the local community development The importance of the government's joint network with the community to ensure the community program runs smoothly with the collaboration and financial aids like donations and sponsorships. By referring administrators of the local government,

"As I said. Our top is MPPWP. Under MPPWP we have a community association, we have a Kawasan Rukun Tetangga (KRT), we have a surau committee, we have several other NGOs. So everything will connect directly to $M P P W P$ ". (PR05/5: 24).

The expert also explained how transparency applied within PPj where

"MPPWP can connect directly with PPj and also the community to show transparency. The top can know what the bottom is. And the bottom can provide information to the top management". (PR05/5:30).

Efficient governance of the resident associations creates an atmosphere of good local community administration. This is important because the community needs efficient governance of resident association's environment to create a resilient community.

The key informant believed that the leader must be active, has the knowledge, experience and the most important thing has no particular interests. When a leader has a particular interest he will affect the community development. Table 3 shows a result from localizing of urban community indicators. 
International Conference on Recents Advancements in Engineering and Technology (ICRAET-18) |15th and 16th March 2019|Siddhartha Institute of Technology \& Sciences, Telangana, India.

Table 3. Urban Community Resilience Indicators in Putrajaya, Malaysia

\begin{tabular}{|c|c|c|}
\hline Dimension & Themes & Localized Indicators \\
\hline \multirow[t]{3}{*}{$\begin{array}{l}\text { Community } \\
\text { capacity } \\
\text { Wilson } \\
(2012)\end{array}$} & $\begin{array}{l}\text { Economic } \\
\text { capital }\end{array}$ & 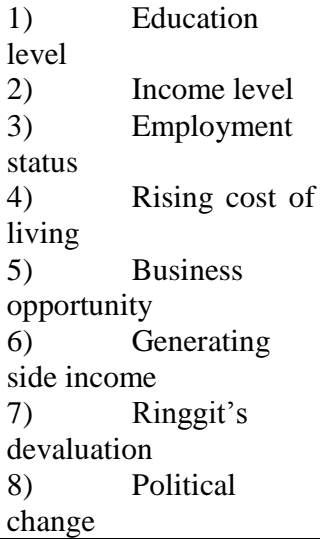 \\
\hline & Social capital & $\begin{array}{l}\text { 1) Active } \\
\text { involvement of the } \\
\text { community } \\
\text { 2) Networking } \\
\text { community through } \\
\text { associations } \\
\text { 3) Urban } \\
\text { community resident } \\
\text { associations } \\
\text { 4) Community } \\
\text { social support } \\
\text { 5) Support of } \\
\text { local community in } \\
\text { activities }\end{array}$ \\
\hline & $\begin{array}{l}\text { Environmental } \\
\text { capital }\end{array}$ & $\begin{array}{l}\text { 1) Initiatives to } \\
\text { protect the environment } \\
\text { 2) Initiatives in } \\
\text { utilizing natural } \\
\text { resources } \\
\text { 3) Governance } \\
\text { of urban community } \\
\text { resident associations } \\
\text { 4) Networking } \\
\text { with the government }\end{array}$ \\
\hline
\end{tabular}

\section{CONCLUSION}

Community development based on the resilience concept is growing rapidly especially in metropolitan cities. Malaysia also has embraced the concept of resilience especially in the formation of urban resilience. Putrajaya, Kuala Lumpur and Malacca cities have been selected by the government as examples of cities in the city's resilient campaign to be emulated across the country. Nevertheless, the result of the previous studies found that there is gap in the implementation of resilient community concept. The gap is seen in which resilience study in previous research more sectoral in nature and in particular perspectives. Resilience studies in Malaysia have given priority to the city's resilient to natural disasters such as flash floods that occur locally. Therefore, current research acknowledges the additional indicators for urban community resilience by localizing the indicators that have been adapted from previous scholars in order to build a comprehensive guide for assessing the resilience level of urban community.

\section{REFERENCES}

1. Jumain F, Ashaha R, Firdaus J. Revolusi Perindustrian 4.0: Bersediakah kita? Sinar Online. 2017.
2. Razak PTSDA. Revolusi Industri Ke-4: Mampukah Menginsankan Teknologi? Majalah Sains. 2017.

3. Foundation TR, ARUP. City Resilience Index. 100 Resilient Cities. 2015(December): 16

4. Rahman AA, Ahmad AR, Malek JA, Awang MM Penglibatan Sosial dan Pembudayaan Nilai Murni Melalui Pembelajaran Tidak Formal Dalam Kalangan Penduduk Bandar Putrajaya. Kajian Malaysia 2016;34(2):75-100.

5. Zautra A, Hall J, Murray K. Community Development and Community Resilience: An Integrative Approach. Journal of the Community Development Society. 2009;39(1):130-47.

6. Longstaff PH, Armstrong NJ, Perrin K, Parker WM, Hidek MA. Building Resilient Communities: A Preliminary Framework for Assessment. Homeland Security Affairs. 2010;6(3).

7. Cutter SL, Barnes L, Berry M, Burton C, Evans E, Tate E, et al. A Place-based Model for Understanding Community Resilience to Natural Disasters. Global Environmental Change. 2008;18:598-606.

8. Wilson GA. Community Resilience, Globalization, and Transitional Pathways of Decision-making. Geoforum. 2012;43:1218-31.

9. Kumar R. Research Methodology SAGE Publications; 2011.

10. Idris N. Penyelidikan Dalam Pendidikan. Malaysia: McGraw-Hill Education Malaysia; 2013.

\section{AUTHORS PROFILE}

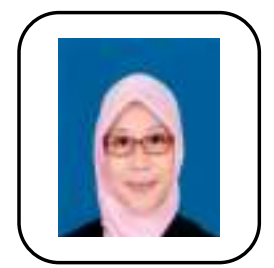

Norhidayah Mohamad is an ambitious person that interested in professional development and researching, ongoing learning and growth, who likes to communicate and working with new ideas and people. She currently pursues her Master of Philosophy (M.Phil) in Development Science at Universiti Kebangsaan Malaysia (UKM). She earned a Bachelor of Administrative Science (Honours) in 2016 from Universiti Teknologi Mara (UiTM). Her main research interests are in the areas of resilience community, urban community and community development.

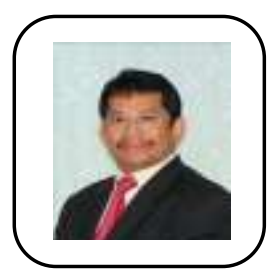

Prof. Dr. Hamzah Jusoh is currently a professor in the Program of Development Sciences, Faculty of Social Sciences and Humanities, Universiti Kebangsaan Malaysia. He has extensive experienced in academic administration, currently as Deputy Dean (Undergraduate), Faculty of Social Sciences and Humanities. As an academician who has a strong background in the field of urban and regional planning, he has more than 30 years experiences in teaching courses at the undergraduate and postgraduate studies in areas related to urban planning and development and urbanization, regional economic development, globalization and development. He is also a prolific researcher in the field of urban and regional planning. He is among a small number of researchers in Malaysia, involved in research on global cities, especially in the city of Kuala Lumpur. Even his benchmarking subject of globalization has generated debate as early as 1995, since he was one of the book's editors of ASEAN In the Global System, which was published by UKM. His latest book entitled Global City: Dynamics of Kuala Lumpur which was published in 2014 by UKM Publisher. His expertise and experiences in the fields of urban and regional planning and development allows him to present various papers at conferences in the country and abroad. His works have been published in various conference proceedings, journals, both nationally and internationally, as well as chapters in books. 
Dr Zarina Kassim has completed Doctor of Philosophy at Universiti Kebangsaan Malaysia. Dr Zarina's broad academic interests involve Economics Education, Entrepreneurship, Adult \& Continuing Education, Small and Medium Enterprises (SME's), Economics Development and Politics and Economics. She is currently a researcher at Faculty of Economics \& Administration, University of Malaya, Malaysia. She has published several academic articles in national and international refereed journals. 